\title{
Synthesis and Determination of Antitumor Activity of Jacaranone and Synthetic Analogs
}

\author{
María L. Arias ${ }^{1}$, Eugenia Corrales ${ }^{1}$, Rebeca Poveda², Jorge A. Cabezas ${ }^{2 *}$ \\ ${ }^{1}$ ResearchCenter for Tropical Disease (CIET) and Faculty of Microbiology, University of Costa Rica, San José, Costa Rica \\ ${ }^{2}$ School of Chemistry, University of Costa Rica, San José, Costa Rica \\ Email: *jorge.cabezas@ucr.ac.cr
}

How to cite this paper: Arias, M.L., Corrales, E., Poveda, R. and Cabezas, J.A. (2018) Synthesis and Determination of Antitumor Activity of Jacaranone and Synthetic Analogs. International Journal of Organic Chemistry, 8, 115-124.

https://doi.org/10.4236/ijoc.2018.81007

Received: December 19, 2017

Accepted: March 4, 2018

Published: March 7, 2018

Copyright $\odot 2018$ by authors and Scientific Research Publishing Inc. This work is licensed under the Creative Commons Attribution International License (CC BY 4.0).

http://creativecommons.org/licenses/by/4.0/

\begin{abstract}
Natural product jacaranone, 1 , and three analog derivatives were synthesized and their apoptotic and necrotic activity against four cancer cell lines was tested. One of these derivatives 7 , was more active than the natural product, and exhibited an important necrotic effect against three of the cell lines tested (ovarian carcinoma, liver cancer and breast cancer cells). Derivative 6 was more active than the natural product, and showed a significant apoptotic activity against breast cancer and ovarian carcinoma cells. Some derivatives analyzed in this study showed promising anti-tumor results, nevertheless, further studies have to be done in order to determine their in vivo activity, their mechanism as well as their safety and stability.
\end{abstract}

\section{Keywords}

Jacaranone, Jacaranone Synthetic Analogs, Antitumor Activity

\section{Introduction}

In 1976, Farnsworth et al. reported [1] that methanolic extracts from the plant Jacaranda caucana (Bignoniaceae) showed activity against P-388 lymphocytic leukemia. The compound responsible for this activity was a benzoquinoid (a quinol) named as jacaranone, 1 . Since then, this phytoquinoid has been isolated from many species of flowering plants of the families Asteraceae (or Compositae) [2] and Bignoniaceae [3], both widely distributed in the tropical and subtropical areas of the world [4]. Jacaranone, 1, has also been isolated from plants of the Pentaphylacaceae family [5] and from the algae Delesseria sanguinea (Delesseriaceae) [6].

It has been reported that Jacaranone, 1, possesses a broad biological activity: antitumor activity and induces apoptosis in murine melanoma cells [7], mod- 
erate activity against leishmaniasis [8], cytotoxic activity against prostate carcinoma cell lines [9], antibacterial activity [10] [11], and anti-malarial and anti-trypanosomal activity [12].

Conventional antitumor cytotoxic chemotherapies include the use of several natural products and derivatives [13] [14], some of them possessing quinones in its structure [15] such as daunorubicin, also named as daunomycin, a medication used to treat several types of leukemia. These quinones have the ability to form oxygen reactive species (ROS) [16], a group of highly reactive chemicals controlled by intracellular antioxidants. Low levels of ROS may produce cell proliferation and genetic instability, but at high concentration can promote apoptosis, and act as cancer suppressor species [7]. This controversial capacity may be due to the varying antioxidant capacities of different cancers [17].

The definition of a dead cell and its influence over the immune system response has been controversial. This approach is based on the theory that distinct types of cell death induce different types of immune responses, for example, physiological cell death or apoptosis is intrinsically tolerogenic [18]. Pathological cell death or necrosis is inherently immunogenic and induces an inflammatory reaction. Nevertheless, there is evidence of cells dying by apoptosis that are vigorously immunogenic, and necrotic cells that are less immunogenic [18]. One of the last theories about dead cells establishes that there are subcategories for both apoptotic and necrotic cells (immunogenic and non-immunogenic), and that there are subtle differences in the composition of the cell surface or its products that determine whether the death of a cell will be immunogenic or not [19].

Based on this theory, the aim of this study was to synthesize quinol jacaranone, 1 , and several synthetic analogs 5-7, and to evaluate their antitumor activity against four different cancer cell lines including ovarian carcinoma, breast cancer, liver cancer and leukemia cells, considering both necrotic and apoptotic effects in order to evaluate its potential use as anticancer therapy.

\section{Materials and Methods}

\subsection{Synthesis. General Information}

All glassware and syringes were dried in an oven overnight at $140^{\circ} \mathrm{C}$ and flushed with nitrogen immediately prior to use. Transfers of reagents were performed with syringes equipped with stainless-steel needles. All reactions were carried out under a positive pressure of nitrogen. Nitrogen was passed through a Drierite gas-drying unit. Diethyl ether and tetrahydrofuran were refluxed and freshly distilled from sodium and potassium/benzophenone ketyl respectively, under nitrogen atmosphere. Diisopropylamine was distilled from sodium, under nitrogen, immediately prior to use. $n$-Butyllithium was titrated with 2-butanol and 1,10-phenathrolin was used as indicator. ${ }^{1} \mathrm{H}-\mathrm{NMR}$ and ${ }^{13} \mathrm{C}-\mathrm{NMR}$ spectra were recorded on a $400 \mathrm{MHz}$ Bruker spectrometer. High resolution mass were measured on a Waters Synapt HMDS G1, Q-TOF. Infrared spectra were recorded on 
a Perkin Elmer FT-IR Spectrum 1000.

\subsection{Synthesis of Jacaranone Derivatives}

In a three necked $50 \mathrm{~mL}$ round bottom flask, equipped with a magnetic stirring bar, and an addition funnel with pressure-equalizing arm, capped with a rubber septum, diisopropylamine $(0.5 \mathrm{~mL}, 3.7 \mathrm{mmol})$ and THF $(10 \mathrm{~mL})$ were added and cooled to $-30^{\circ} \mathrm{C}$. A solution of $n$ - BuLi in hexanes $(1.55 \mathrm{~mL}, 3.7 \mathrm{mmol})$ was added dropwise and the solution stirred for 20 minutes. The temperature was lowered to $-78^{\circ} \mathrm{C}$ and the corresponding acetate $(3.7 \mathrm{mmol})$ in THF $(6 \mathrm{~mL})$ was added dropwise through the addition funnel and the resulting solution stirred for 40 additional minutes at this temperature.

In a second assembly a three-necked $250 \mathrm{~mL}$ round-bottom flask, equipped with a magnetic stirring bar and a dry-ice jacketed addition funnel with pressure-equalization arm was charged with $p$-benzoquinone $(3.7 \mathrm{mmol}, 0.40 \mathrm{~g})$ and $190 \mathrm{~mL}$ of dry diethyl ether and cooled to $-78^{\circ} \mathrm{C}$. The ester enolate, prepared as above, was transferred via a double-tipped needle to the jacketed funnel, maintained at $-78^{\circ} \mathrm{C}$ and the solution was added dropwise to the $p$-benzoquinone over $45 \mathrm{~min}$. The mixture was allowed to gradually warm to $-20^{\circ} \mathrm{C}$ and quenched by the addition of ethanol $95 \%\left(1.33 \mathrm{~g}, 3.7 \mathrm{mmol} \mathrm{H}_{2} \mathrm{O}\right)$. The mixture was allowed to reach room temperature, was filtered through a florisil/anhydrous sodium sulfate pad, eluted with ether, and then the solvent was evaporated in vacuo. The residue obtained was purified by column chromatography, using a mixture of hexanes:ether in a 7:3 ratio.

\section{Spectroscopic Characteristics}

2,5-Cyclohexadiene-1-acetic acid, 1-hydroxy-4-oxo-methyl ester (Jacaranone), 1.

${ }^{1} \mathrm{H}-\mathrm{NMR}\left(400 \mathrm{MHz}, \mathrm{CDCl}_{3}\right) \delta: 2.70(\mathrm{~s}, 2 \mathrm{H}), 3.76(\mathrm{~s}, 3 \mathrm{H}), 3.94(\mathrm{~s}, 1 \mathrm{H}), 6.21(\mathrm{~m}$, $2 \mathrm{H}, J=10.2 \mathrm{~Hz}), 6.96(\mathrm{~m}, 2 \mathrm{H}, J=10.2 \mathrm{~Hz}) ;{ }^{13} \mathrm{C}-\mathrm{NMR}\left(100 \mathrm{MHz}, \mathrm{CDCl}_{3}\right) \delta: 43.2$, 52.3, 67.4, 128.3, 148.8, 171.4, 184.9; IR $v_{\max }\left(\right.$ film) $\mathrm{cm}^{-1}: 3406(\mathrm{OH}), 2971,2875$, $1733(\mathrm{C}=\mathrm{O}), 1672(\mathrm{C}=\mathrm{O}), 1629(\mathrm{C}=\mathrm{C}), 1049$; MS (EI): $\mathrm{m} / \mathrm{z}$ (rel intensity) 43.1 (14), 53.1 (12), 74.1 (58), 81.1 (37), 94.1 (9), 109.1 (100), 122.1 (19), 150.1 (22), 182.1 (6); HRMS $\left(E S I, \mathrm{~V}^{+}\right): m / z[\mathrm{M}+\mathrm{H}]^{+}$calc. for $\mathrm{C}_{9} \mathrm{H}_{10} \mathrm{O}_{4}: 183.0657$, found 183.0655 .

2,5-Cyclohexadiene-1-acetic acid, 1-hydroxy-4-oxo-geranyl ester, 5.

${ }^{1} \mathrm{H}-\mathrm{NMR}\left(400 \mathrm{MHz}, \mathrm{CDCl}_{3}\right.$ ) $\delta: 1.58$ (s, 3H), 1.60 (s, 3H), 1.68 (b s, 3H), 2.08 $(\mathrm{m}, 4 \mathrm{H}), 2.68(\mathrm{~s}, 2 \mathrm{H}), 4.07(\mathrm{~s}, 1 \mathrm{H}), 4.68(\mathrm{~d}, 2 \mathrm{H}, J=7.2 \mathrm{~Hz}), 5.07(\mathrm{~m}, 1 \mathrm{H}), 5.33$ (tq, $1 \mathrm{H}, J=7.2,1.1 \mathrm{~Hz}), 6.20(\mathrm{~m}, 2 \mathrm{H}, J=10.2 \mathrm{~Hz}), 6.94(\mathrm{~m}, 2 \mathrm{H}, J=10.2 \mathrm{~Hz})$; ${ }^{13} \mathrm{C}-\mathrm{NMR}\left(100 \mathrm{MHz}, \mathrm{CDCl}_{3}\right) \delta: 16.5,17.7,25.7,26.2,39.5,43.4,62.4,67.4,117.3$, $123.5,128.3,132.0,143.7,148.8,171.0,184.9$; IR $V_{\max }\left(\right.$ film) $\mathrm{cm}^{-1}: 3650,3600$, 3350, 2950, 2900, $1720(\mathrm{C}=\mathrm{O}), 1670(\mathrm{C}=\mathrm{O}), 1630(\mathrm{C}=\mathrm{C}), 960$; MS (EI): $\mathrm{m} / z(\mathrm{rel}$ intensity) 41.1 (40), 53.1 (14), 69.1 (100), 81.1 (26), 93.1 (56), 109.1 (26), 136.2 (20), 150.1 (6), 168.1 (3); HRMS (ESI, $\left.\mathrm{V}^{+}\right): m / z[\mathrm{M}+\mathrm{H}]^{+}$calc. for $\mathrm{C}_{18} \mathrm{H}_{24} \mathrm{O}_{4}$ : 305.1753 , found 305.1753 .

2,5-Cyclohexadiene-1-acetic acid, 1-hydroxy-4-oxo-benzyl ester, 6. 
${ }^{1} \mathrm{H}-\mathrm{NMR}\left(400 \mathrm{MHz}, \mathrm{CDCl}_{3}\right) \delta: 2.74(\mathrm{~s}, 2 \mathrm{H}), 3.90$ (broad s, $\left.1 \mathrm{H}\right), 5.18(\mathrm{~s}, 2 \mathrm{H})$, $6.17(\mathrm{~m}, 2 \mathrm{H}, J=10.3 \mathrm{~Hz}), 6.93(\mathrm{~m}, 2 \mathrm{H}, J=10.3 \mathrm{~Hz}), 7.36(\mathrm{~m}, 5 \mathrm{H}) .{ }^{13} \mathrm{C}-\mathrm{NMR}(100$ $\left.\mathrm{MHz}, \mathrm{CDCl}_{3}\right) \delta: 43.5,67.3,67.4,128.3,128.4,128.7,128.7,134.9,148.7,170.6$, 184.6; IR $V_{\max }($ film $) \mathrm{cm}^{-1}: 3388(\mathrm{OH}), 1716(\mathrm{C}=\mathrm{O}), 1671(\mathrm{C}=\mathrm{O}), 1626(\mathrm{C}=\mathrm{C})$, 1241 (C-O); MS (EI): $m / z$ (rel intensity) 51.1 (7), 65.1 (9), 77.1 (14), 79.1 (14), 91.1 (100), 107.1 (30), 134.1(14), 150.1 (6), 207.1 (6), 242.2 (4); HRMS (ESI, V ${ }^{+}$): $m / z[\mathrm{M}+\mathrm{H}]^{+}$calc. for $\mathrm{C}_{15} \mathrm{H}_{14} \mathrm{O}_{4}: 259.1000$, found 259.0983 .

2,5-Cyclohexadiene-1-acetic acid, 1-hydroxy-4-oxo-(3-dimethylamino)benzyl ester, 7.

${ }^{1} \mathrm{H}-\mathrm{NMR}\left(400 \mathrm{MHz}, \mathrm{CDCl}_{3}\right.$ ) $\delta: 2.73$ (s, 2H), 2.96 (s, 6H), 4.00 (br s, 1H), 5.14 $(\mathrm{s}, 2 \mathrm{H}), 6.17(\mathrm{~m}, 2 \mathrm{H}, J=10.0 \mathrm{~Hz}), 6.69(\mathrm{~m}, 3 \mathrm{H}), 6.94(\mathrm{~m}, 2 \mathrm{H}, J=10.0 \mathrm{~Hz}), 7.23$ $(\mathrm{dd}, 1 \mathrm{H}, J=7.8,7.8 \mathrm{~Hz}) ;{ }^{13} \mathrm{C}-\mathrm{NMR}\left(100 \mathrm{MHz}, \mathrm{CDCl}_{3}\right) \delta: 40.5,43.6,67.4,67.9$, $112.3,112.7,116.4,128.3,129.4,135.7,148.9,150.8,170.7,184.9$; IR $V_{\max }$ (film) $\mathrm{cm}^{-1}$ : $3444(\mathrm{OH}), 1737(\mathrm{C}=\mathrm{O}), 1671(\mathrm{C}=\mathrm{O}), 1606(\mathrm{C}=\mathrm{C}), 1229(\mathrm{C}-\mathrm{O})$; MS (EI): $\mathrm{m} / z$ (rel intensity) 43.1 (12), 65.1 (7), 77.1 (15), 91.1 (26), 107.2 (11), 122.2 (48), 134.2 (31), 150.2 (45), 193.2 (100); HRMS (ESI, $\left.\mathrm{V}^{+}\right): m / z[\mathrm{M}+\mathrm{H}]^{+}$calc. for $\mathrm{C}_{17} \mathrm{H}_{19} \mathrm{O}_{4}: 302.1392$, found 302.1389 .

\subsection{Cell Lines and Culture Conditions}

SKOV-3 (ovary adenocarcinoma cells, ATCC ${ }^{\circledast} \mathrm{HTB}^{\mathrm{T}} \mathrm{7}^{\mathrm{TM}}$ ), MCF7 (breast adenocarcinoma cells, ATCC ${ }^{\circledast}$ HTB-22 $2^{\mathrm{im}}$ ), Hep-G2 (hepatocellular carcinoma cells ATCC $^{\circledast}$ HB- $8065^{\mathrm{TM}}$ ), and CCRF-CEM (acute lymphoblastic leukemia, T lymphoblast cells, ATCC ${ }^{\circledast}$ CCL-119 ${ }^{\mathrm{rm}}$ ) were maintained in RPMI-1640 + GlutaMAX-I ${ }^{\mathrm{TM}}$ (Gibco) supplemented with $10 \mathrm{mM}$ N-2-hydroxyethylpiperazine-N2 ethanesulphonic acid (HEPES; Sigma-Aldrich) and 10\% fetal bovine serum (Gibco) at $37^{\circ} \mathrm{C}$ with a $5 \% \mathrm{CO}_{2}$ atmosphere.

\subsection{Annexin V and Propidium Iodide Labeling}

Apoptotic, necrotic and viable cells were quantified using an Annexin $\mathrm{V}$ and propidium iodide labeling kit (Dead Cell Apoptosis Kit with Annexin V Alexa Fluor $^{\mathrm{TM}} 488 \&$ Propidium Iodide (PI), Molecular Probes ${ }^{\circledast}$ ). Briefly $1 \times 10$ E5 cells per well were cultured in 48 -well plates and further incubated with $10 \mu \mathrm{g} / \mathrm{ml}$ of jacaranone 1, jacaranone ester side-chain analogs 5-7, a positive control drug Epirubicin (Pfizer) $(2 \mu \mathrm{g} / \mathrm{ml}$ ), and DMSO (as negative control) during $24 \mathrm{~h}$ at $37^{\circ} \mathrm{C} 5 \% \mathrm{CO}_{2}$. Treated and untreated cells were washed two times with PBS and harvested with $\mathrm{HyO}^{\circledR}$ Tase (HyClone). Apoptotic/necrotic cells were detected using the Dead Cell Apoptosis Kit with Annexin V Alexa Fluor ${ }^{\mathrm{Tm}} 488$ \& Propidium Iodide (PI) Kit following the manufacturer's instructions. Cells were incubated with binding buffer (10 mM HEPES/NaOH, pH 7.5, $140 \mathrm{mM} \mathrm{NaCl}$ and $2.5 \mathrm{mM}$ $\mathrm{CaCl}_{2}$ ) in the presence of propidium iodide (PI) and Alexa Fluor ${ }^{\mathrm{TM}} 488$-labeled Annexin V (AV) for $15 \mathrm{~min}$ at room temperature and analyzed by flow cytometry (BD Accuri ${ }^{\mathrm{rm}}$ C6 Flow Cytometer, BD Biosciences). Results were analyzed using FlowJo software (TreeStar Inc.). 


\subsection{Statistical Analysis}

Data were analyzed using ANOVA. Each analysis was done in triplicate.

\section{Results}

The synthesis of jacaranone, 1, and jacaranone ester side-chain analogs (5-7) was performed by the addition of a cold $\left(-78^{\circ} \mathrm{C}\right)$ THF solution of the corresponding lithium ester enolates, 3 , over a cold $\left(-78^{\circ} \mathrm{C}\right)$ ether solution of p-benzoquinone, 4 , as outlined in Scheme 1 , and according to a previous procedure [11].

The lithium enolates, 3 , were prepared by treatment of a cold $\left(-30^{\circ} \mathrm{C}\right) \mathrm{THF}$ solution of LDA, with the corresponding acetates, 2 . Jacaranone derivatives synthesized are showed on Figure 1.

The apoptotic and necrotic activities of jacaranone, 1, and synthetic derivatives were measured and it is shown on Figure 2 and Figure 3. As seen on Figure 2, compounds 5 and 6 show significantly higher apoptotic activity compared

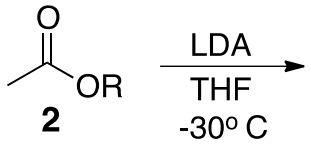<smiles>C=C(O)O</smiles>

1.<smiles>O=C1C=CC(=O)C=C1</smiles>

2. $\mathrm{EtOH} 95 \%$ $-20^{\circ} \mathrm{C}$<smiles>O=C1C=CC(O)(CC(=O)O)C=C1</smiles>

1, $\mathrm{R}: \mathrm{CH}_{3}$

Scheme 1. Synthesis of jacaranone, $\mathbf{1}$, and ester analogs.<smiles>COC(=O)CC1(O)C=CC(=O)C=C1</smiles>

1<smiles>O=C1C=CC(O)(CC(=O)OCc2ccccc2)C=C1</smiles><smiles>CC(C)=CCC/C(C)=C/COC(=O)CC1(O)C=CC(=O)C=C1</smiles><smiles>CN(C)c1cccc(COC(=O)CC2(O)C=CC(=O)C=C2)c1</smiles>

Figure 1. Jacaranone, 1, and ester analogs synthesized. 


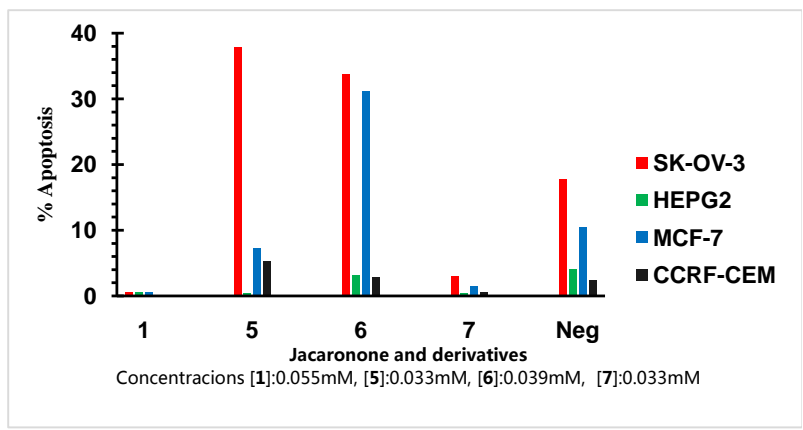

Figure 2. Apoptosis induced by jacaranone, 1, and derivatives in cancer cell lines.

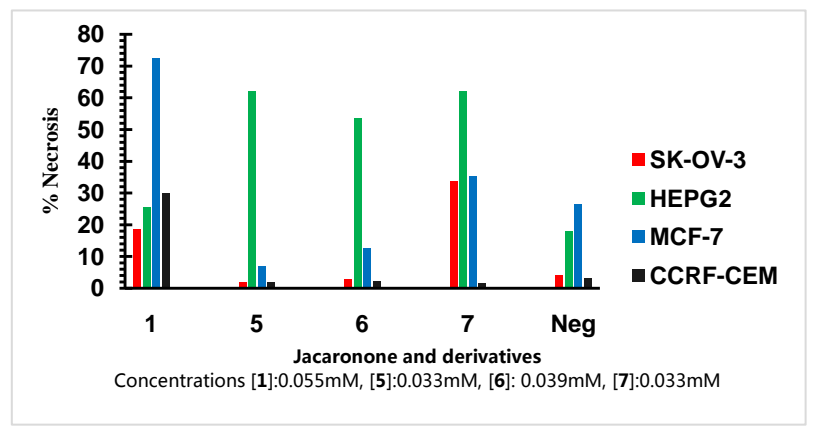

Figure 3. Necrosis induced by jacaranone, 1, and derivatives in cancer cell lines.

with jacaranone, $\mathbf{1}$ and the negative control for ovarian and breast cancer cells. Accordingly, compound $\mathbf{7}$ shows an important necrotic activity when compared with jacaranone, $1,(\mathrm{p}<0.05)$ (Figure 3$)$.

For HepG2 liver cancer cells, the necrotic activity of compounds 5, 6 and 7 is significantly enhanced when compared with jacaranone, $1,(\mathrm{p}<0.05)$ (Figure 3$)$ nevertheless they do not show an important apoptotic activity.

The apoptotic activity of compound 6 for breast cancer cells MCF-7 is significantly greater than any other compound tested $(\mathrm{p}<0.05)$ (Figure 2$)$. An important necrotic activity is shown for jacaranone, 1 , and 7 for the same breast cancer cells (Figure 3). Jacaranone, 1 , shows a very strong necrotic activity against CCRF-CEM Leukemia cells, but analog compounds (5-7) do not show any necrotic or apoptotic activity against these cells (Figure 2 and Figure 3 ).

\section{Discussion}

Necrosis and apoptosis are two pathways of cell death resulting in distinct cell morphologies. Necrosis is understood as a cellular metabolic collapse that occurs when a cell is not able to maintain its ionic homeostasis [20]. ATP is exhausted, transmembrane ion gradients are disrupted, internal organelles become distended because of cell swelling, and lysosomal enzymes are spilled out. All these processes produce a non-specific inflammatory response [20].

Apoptosis is normally understood as a programmed cell death. Apoptotic cells 
lose contact with neighbors, decrease in size, chromatin condensates and cell membrane becomes rigid. These cells are then recognized and eliminated by phagocytes causing a minimal disruption to neighboring cells. An absence of intracellular contents leakage into the extracellular compartment results in scarce or no inflammatory response [20].

These distinct types of cell death and their effect on immune response prompted a hypothesis where physiological cell death or apoptosis was considered as intrinsically tolerogenic, whereas pathological cell death or necrosis was considered inherently immunogenic, consequently producing inflammatory response [21]. The response of immune system has been considered as transcendental for the elimination of tumor cells after treatment with chemotherapeutic agents [22]. Nevertheless, actual knowledge has revealed that certain types of apoptotic deaths can be immunogenic [17], so the dichotomy between necrosis and apoptosis does not predict immunogenicity or tolerance [21].

Jacaranone, 1, and synthetic analogs analyzed here (5-7) induce both apoptosis and necrosis in different cancer cell lines (Figure 2 and Figure 3). Ideally, immunogenic or necrotic cell death should occur in tumors and infections, while tolerogenic cell death should occur where inflammatory response is unwanted in order to protect organs from excessive inflammation or evading autoimmune responses [21].

Of the compounds analyzed here, derivate $\mathbf{7}$ exhibits an outstanding necrotic activity against three of the four cell lines tested, including ovarian, breast and hepatic cancer cell lines (Figure 3). These results indicate a promissory antitumor activity for this compound.

The antitumoral potential of quinones has been known for many years; indeed some common chemotherapeutic agents, used for the treatment of cancer, have this chemical nucleus [23]. Although there has been a lot of research associated to these compounds and derivatives, the exact toxicity mechanism has not been yet well described, nevertheless, the production of free radicals and oxygen reactive species (ROS) have been shown to have a preponderant anti-tumor role [24]. It has been suggested [7] that jacaranone, $\mathbf{1}$, a quinol, acts with a very similar mechanism as quinones, producing ROS, inducing apoptosis in melanoma cells [7].

Our results indicate that jacaranone, 1, and derivatives (5-7) show both necrotic and apoptotic activities over cell lines tested, activities that might be exploited for therapeutic targeting of tumor tissue. Similar results have been reported by others for Hep-G2, and MDA MB231 cell lines (hepatocarcinoma and breast adenocarcinoma) [25] [26].

Jacaranone, 1, has shown antitumor activity in vitro against several human cancer cell lines, and induction of apoptosis in murine melanoma cells in vivo. Massaoka et al. have demonstrated that jacaranone induces antiproliferative and proapoptotic responses, by acting on Akt and p38 MAPK signaling pathways through the generation of reactive oxygen species (ROS) [7]. 
In cancer cells, ROS signaling plays a major role in tumor formation and development, leading even to the activation of genes associated with the pathogenesis of specific tumors [27]. Superoxide anions and hydrogen peroxide are generated; nevertheless, these two species behave differently regarding cell signaling. Superoxide anions act as oncogenic ROS, while hydrogen peroxide leads to the apoptosis of cancer cells [28].

Massaoka et al. reported [7] that jacaranone, 1, generates ROS causing oxidative stress, producing enhanced activity of the antioxidant defense system and consequently mitochondrial damage.

High level of ROS in cancer cells has been exploited for developing new therapeutic strategies to kill cancer cells [29] [30], thus jacaranone, 1, and derivatives 5-7 might have a roll in this new trend.

The main objective of this study was to devise chemical products that might have anti-tumor activity. The compounds analyzed in this study showed promising results, especially because they are very active at very low concentrations (0.033 - $0.055 \mathrm{mM})$. Nevertheless, further studies have to be done in order to determine their in vivo activity, their mechanism as well as their safety and stability.

\section{Conclusions}

In summary, we prepared natural product jacaranone, 1 , and three synthetic analogs and measured its necrotic and apoptotic activity against several cancer cells. Some of these synthetic derivatives showed promising anti-tumor results.

Derivative 6 was significantly more active than the natural product, showing a significant apoptotic activity against breast cancer and ovarian carcinoma cells. Compound 5, showed significant apoptotic activity against ovarian cancer cells. The apoptotic activity of compound 6 for breast cancer cells MCF-7 is significantly greater than any other compound tested $(\mathrm{p}<0.05)$ (Figure $2(\mathrm{~b})$ ).

Of the compounds analyzed here, derivate $7 \mathbf{b}$, exhibits an outstanding necrotic activity against three of the four cell lines tested, including ovarian, breast and hepatic cancer cell lines (Figure 3 ). These results indicate a promissory antitumor activity for this compound.

For HepG2 liver cancer cells, the necrotic activity of compounds 5, 6 and 7 is significantly enhanced when compared with jacaranone, $1,(\mathrm{p}<0.05)$ (Figure 3 ) nevertheless they do not show an important apoptotic activity.

\section{Acknowledgements}

We thank Vicerrectoría de Investigación, Universidad de Costa Rica for financial support, CIPRONA-UCR for high-resolution mass spectra determination and the School of Chemistry for NMR spectra.

\section{References}

[1] Ogura, M., Cordell, G.A. and Farnsworth, N.R. (1976) Potential Anticancer Agents 
III. Jacaranone, a Novel Phytoquinoid from Jacaranda caucana. Lloydia, 39, 255-257.

[2] Jakupovic, J., Chau-Thi, T.V. and Castro, V. (1987) Cyclohexene Derivatives from Pseudogynoxys cunninghammii. Fitoterapia, 58, 187-188.

[3] Santos, C.A, Raslan, D.S., Chiari, E. and Oliveira, A.B. (1999) Bioguided Assay of Jacaranda macrantha cham. (Binoniaceae). Acta Horticulturae, 21, 501-154.

[4] Sidjui, L., et al. (2016) Antibacterial Activity of the Crude Extracts, Fractions and Compounds from the Stem Barks of Jacaranda mimosifolia and Kigelia Africana (Bignoniaceae). Pharmacologia, 7, 22-31. https://doi.org/10.5567/pharmacologia.2016.22.31

[5] Lozada-Lechuga, J., et al. (2010) Isolation of Jacaranone, a Sedative Constituent Extracted from the Flowers of the Mexican Tree Ternstroemia pringlei. Journal of Ethnopharmacology, 127, 551-554. https://doi.org/10.1016/j.jep.2009.11.020

[6] Yvin, J.C., Chevolot, L., Chevolot-Magueur, A.M. and Cochard, J.C. (1985) First Isolation of Jacaranone from an Alga, Delesseria sanguinea. A Metamorphosis Inducer of Pecten larvae. Journal of Natural Products, 48, 814-816. https://doi.org/10.1021/np50041a018

[7] Massaoka, M.H., et al. (2012) Jacaranone Induces Apoptosis in Melanoma Cells via ROS-Mediated Downregulation of Akt and p38 MAPK Activation and Displays Antitumor Activity in vivo. PLoS One, 7, e38698. https://doi.org/10.1371/journal.pone.0038698

[8] Sauvain, M., et al. (1993) In vitro and in vivo Leishmanicidal Activities of Natural and Synthetic Quinols. Phytotherapy Research, 7, 167-171. https://doi.org/10.1002/ptr.2650070215

[9] Loizzo, M.R., Tundis, R., Statti, G.A. and Menichini, F. (2007) Jacaranone: A Cytotoxic Constituent from Senecio ambiguus Subsp. Ambiguus (Biv.) DC. against Renal Adenocarcinoma ACHN and Prostate Carcinoma LNCaP Cells. Archives of Pharmacal Research, 30, 701-707. https://doi.org/10.1007/BF02977631

[10] Cabezas, J.A., Cicció, J.F., Hidalgo, G. and Echandi, G. (1991) Synthesis and Antibacterial Activity of Jacaranone Ester Side Chain Analogs. Revista Latinoamericana de Química, 22, 49-52.

[11] Arias, M.L., Poveda, R. and Cabezas, J.A. (2017) Synthesis and Determination of Antibacterial Activity of Jacaranone and Synthetic Analogs. International Journal of Current Research, 5, 918-924.

[12] Morais, T.R. (2012) Anti-Malarial, Anti-Trypanosomal, and Anti-Leishmanial Activities of Jacaranone Isolated from Pentacalia Desiderabilis (Vell.) Cuatrec. (Asteraceae). Parasitology Research, 110, 95-101. https://doi.org/10.1007/s00436-011-2454-9

[13] Demain, A.L. and Vaishnav, P. (2011) Natural Products for Cancer Chemotherapy. Microbial Biotechnology, 4, 687-699. https://doi.org/10.1111/j.1751-7915.2010.00221.x

[14] Woldemichael, G.M., Turbyville, T.J., Linehan, W.M. and McMahon, J.B. (2011) Carminomycin 1 is an Apoptosis Inducer That Targets the Golgi Complex in Clear Cell Renal Carcinoma Cells. Cancer Research, 71, 134-142. https://doi.org/10.1158/0008-5472.CAN-10-0757

[15] Powis, G. (1989) Free Radical Formation by Antitumor Quinones. Free Radical Biology and Medicine, 6, 63-101. https://doi.org/10.1016/0891-5849(89)90162-7

[16] Trachootham, D., Alexandre, J. and Huang, P. (2009) Targeting Cancer Cells by 
ROS Mediated Mechanisms: A Radical Therapeutic Approach. Nature Reviews Drug Discovery, 8, 579-591. https://doi.org/10.1038/nrd2803

[17] Yang, Y., Karakhanova, S., Werner, J. and Bazhin, A.V. (2013) Reactive Oxygen Species in Cancer Biology and Anticancer Therapy. Current Medicinal Chemistry, 20, 3677-3692. https://doi.org/10.2174/0929867311320999165

[18] Casares, N., et al. (2005) Caspase-Dependent Immunogenicity of Doxorubicin-Induced Tumor Cell Death. Journal of Experimental Medicine, 202, 1691-1709. https://doi.org/10.1084/jem.20050915

[19] Obeid, M., et al. (2007) Calreticulin Exposure Dictates the Immunogenicity of Cancer Cell Death. Nature Medicine, 13, 54-61. https://doi.org/10.1038/nm1523

[20] Dive, C., Gregory, C., Phipps, D., Evans, D., Milner, A. and Wyllie, A. (1992) Analysis and Discrimination of Necrosis and Apoptosis (Programmed Cell Death) by Multiparameter Flow Cytometry. Biochimica et Biophysica Acta, 1133, 275-285. https://doi.org/10.1016/0167-4889(92)90048-G

[21] Thompson, C.B. (1995) Apoptosis in the Pathogenesis and Treatment of Disease. Science, 267, 1456-1462. https://doi.org/10.1126/science.7878464

[22] Green, D., Ferguson, T., Zitvogel, L. and Kroemer, G. (2009) Immunogenic and Tolerogenic Cell Death. Nature Reviews Immunology, 9, 353-363.

[23] Asher, B. (1983) Cytocidal Action of the Quinone Group and Its Relationship to Antitumor Activity. Cancer Research, 43, 481-484.

[24] Rodriguez, E., Gaitan, R., Mendez, D., Martelo, J. and Zambrano, R. (2007) Análogos de quinonas naturales con actividad antibacteriana. Scientia et Technica, 33, 281-283.

[25] Zakharova, O., Ovchinnikova, P., Goryunov, L., Troshkova, N., Shteingarts, V. and Nevinsky, G. (2010) Cytotoxicity of New Alkylamino- and Phenylamino-Containing Polyfluorinated Derivatives of 1,4-Naphthoquinone. European Journal of Medicinal Chemistry, 45, 2321-2326. https://doi.org/10.1016/j.ejmech.2010.02.009

[26] Kongkathip, N., Kongkathip, B., Siripong, P., Sangma, C., et al. (2003) Potent Antitumor Activity of Synthetic 1,2-Naphthoquinones and 1,4-Naphthoquinones. Bioorganic \& Medicinal Chemistry, 11, 3179-3191. https://doi.org/10.1016/S0968-0896(03)00226-8

[27] Herdon, J.M., Stuart, P.M. and Ferguson, T.A. (2005) Peripheral Deletion of Antigen-Specific T Cells Leads to Long Term Tolerance Mediated by CD8 ${ }^{+}$Cytotoxic Cells. The Journal of Immunology, 174, 4098-4014.

[28] Gasser, S., Orsulic, S., Brown, E.J. and Raulet, D.H. (2005) The DNA Damage Pathway Regulates Innate Immune System Ligands of the NKG2D Receptor. $\mathrm{Na}$ ture, 436, 1186-1190.

[29] Belz, G.T., et al. (2002) The CD8alpha ${ }^{+}$Dendritic Cell Is Responsible for Inducing Peripheral Self-Tolerance to Tissue Associated Antigens. Journal of Experimental Medicine, 196, 1099-1104.

[30] Steinman, R.M., Turley, S., Mellman, I. and Inaba, K. (2000) The Induction of Tolerance by Dendritic Cells That Have Captured Apoptotic Cells. Journal of Experimental Medicine, 191, 411-416. 